\section{Botany and Poison}

THE rabbit has digestive juices which can neutralize the poison of the death cap mushroom-Amanita phalloides-in amounts sufficient to kill a whole human family. Such is the difference in the susceptibility of different species to the effects of plant poisons. Humans are, however, rarely poisoned by plants, whereas poisoning of domestic animals is quite commonplace. Horses and cattle can even develop cravings for such dangerous delicacies as laurel, rhododendron, oak leaves and rushes. To help the stock owner the Ministry of Agriculture's guide, British Poisonous Plants, has been published in a second edition after 14 years (HMSO, $11 s$.$) .$

Most plant poisons are irritants causing inflammation of the tissues with which they come in contact. They affect first the skin and the lining of the mouth, stomach and bowels. Poisons which enter the blood stream may affect any part of the body, but many of them, such as the alkaloids, are selective poisons and affect specialized areas of the body more than others. Their action differs considerably among different animal species. Morphine-from the opium poppy, Papaver somniferum - for example, induces sleep in man and dog, but if given to horse or cat it may produce uncontrollable excitement to the extent that the animal damages itself irreparably.

Sudden death is most likely to be caused by the yew tree and plants which contain cyanogenic poisons which break down to yield hydrocyanic-or prussicacid. Cyanogens are found in apricot, cherry, peach and plum kernels, in apple and pear pips and many other plants. The commonest result of poisoning of cattle, sheep and goats is cessation or suspension of rumination or cud chewing after the breakdown of the micro-organisms which usually effect the breakdown of foodstuffs.

Many plant poisons remain active after drying and storage, which is why so much animal poisoning occurs in the winter when stored foods are used. Poisoning by ragwort, horsetail and monkshood can often be traced back to hay or other stored fodder. These and other such plants, which commonly contain alkaloids, glycosides and saponins, are listed in the handbook together with their likely sources. There is also a list of plants which can affect milk if eaten by lactating cows. In some cases the poisonous principles are secreted by the udders in sufficient quantities to make the milk poisonous for children and calves. Usually, however, the odour or taste is so unpleasant that they would not voluntarily drink such milk.

\section{Canadian National Museums}

THE Canadian Government took the bold step on April 1 of establishing a single independent corporation, to be known as the National Museums of Canada, to administer and integrate the work of the five national museums in Ottawa. The museums which have lost their separate existence are the National Gallery of Canada, the National Museums of Man, of Natural Sciences and of Science and Technology and the Canadian War Museum. The hope is that this reorganization will increase efficiency and improve the services they can offer to the public. There is every chance that it will succeed. With small museums-the total staff is only 374 , or less than that of the British Museum alone-there can be little justification for separate administrations. The new scheme should be a distinct improvement.

The thirteen trustees of the corporation will have at their disposal in 1968-69 a total budget of $\$ 7,344,500$, which includes a $\$ 1,050,000$ non-lapsing purchase account. Compared with the estimated budget of nearly $£ 7.07$ million for 1968-69 for the fifteen national museums and galleries in Britain, that is perhaps small beer. But the comparison is misleading, for Canada spends about as much per head of its population as does Britain; of the $£ 7.07$ million spent in Britain, all but just under $£ 1$ million goes on salaries and administrative costs. When the $£ 1$ million available for purchases is parcelled out among fifteen institutions, the amount each gets is derisory.

The National Gallery in London, for example, receives $£ 200,000$ a year and the Science Museum has not received money for purchases since the $£ 8,000$ it got in the financial year 1966-67. This is not entirely the fault of the Department of Education and Science. The Science Museum, which relies heavily on gifts of objects and apparently spends most of its money on transporting them to the museum, has incredibly enough failed to find anything in the past three years on which to spend its pittance. It is no wonder that it often seems a kind of cheap showroom for the nationalized industries.

\section{New Schools at Oxford}

\section{from our Oxford Correspondent}

LAST week's Oxford Gazette announced a set of measures of particular interest to the university science faculties. There are, for example, to be departmental committees in most, if not all, of the science departments. All the faculty staff working in the department will be members, and they will meet at least once a term to advise the head of the department on such matters as the annual estimates, the allocation of resources, and junior appointments to the staff. Previously, members of a department have only been able to discuss departmental affairs publicly in congregation, where, even if there was time for discussion, few of the members were likely to have been able to follow arguments about specialized topics.

The other changes promised concern the rearrangement of one honours school and the creation of two others. The present four year course in forestry is to be replaced by a three year course of which the first two years will be common to agriculturists and botanists as well as foresters. The forestry officers' course will be replaced by a diploma course for graduates. The faculty of agriculture and forestry is to be subsumed, as a sub-faculty, under the faculty of biological sciences, but the departments of agriculture, forestry and botany will remain separate. This continues the reorganization of the teaching of biological sciences which began four years ago with the inception of a one year common course for agriculturists, botanists and zoologists.

The two new honours schools to be created are those of mathematics and philosophy and of physics and philosophy. While the joint honours schools on the arts side, philosophy, politics and economies, and 